\title{
A VILÁGJÁTÉK-TESZT TÖRTÉNETI BEMUTATÁSA A VILÁGJÁTÉK TÖRTÉNETE
}

\author{
CSENKI LAURA - JAMBRIK MÁTÉ \\ SE ÁOK I. Gyermekgyógyászati Klinika, Gyermek- és Ifjúságpszichiátriai Osztály \\ E-mail: csenki.laura@gmail.com
}

Beérkezett: 2017. április 27. Elfogadva: 2018. augusztus 28.

\begin{abstract}
A tanulmány célja, hogy átfogó történeti áttekintést adjon a Világjáték-teszt kialakulásáról, és bemutassa annak kutatási és diagnosztikai jelentôségét. Az irodalmi összefoglalás egészen a teszt elsố megjelenéséig, 1937-ig nyúlik vissza. Tárgyalja a teszt kialakulásának elméleti hátterét és annak kritikáit, valamint részletesen bemutatja a teszt sztenderdizálására irányuló vizsgálatokat. A Világjáték-teszt pszichodiagnosztikai eszköz, és megjelenése óta központi kérdés, hogy milyen módon alkalmazható a klinikai munkában. A klaszszikus vizsgálatok leirták a tesztben megjelenố jellegzetes tüneti jegyeket és azokra épülô tüneti mintázatokat, melyek megfelelóen differenciálják az egészséges lelki müködést a patológiástól. Az egészséges gyermekkori jegyek alapján fejlódési konfigurációkról vagy normákról beszélhetünk, melyek felnótt mintában is megfigyelhetók. A Világjáték-teszt magyar vizsgálatai nyomán a leíró jegyeken túl mélyebb összefüggések, dinamikai tartalmak is feltárhatóvá válnak, felhívó kérdések és szimbolikus elemzés segitségével. A Világjáték-teszt kutatása az 1970-80-as évekre lecsökkent, s addigi eredményei modern vizsgálati módszertan és friss eredmények hiányában - hasonlóan más projektív tesztekhez - egyre inkább elavultnak tünhetnek. Emellett azonban a teszt gyakorlati alkalmazása széles körben elterjedt, ezért egységes felvételi és értékelési szempontok kidolgozása szükséges. Ennek alapja az elméleti és módszertani áttekintés.
\end{abstract}

Kulcsszavak: Világjáték-teszt, projektív teszt, klinikai pszichológia, pszichodiagnosztika 


\section{BEVEZETÉS}

A projektív tesztek - köztük a Világjáték-teszt - szakmai megítélése igen ambivalens. Megkérdőjelezik relevanciájukat, diagnosztikai értéküket - idejétmúlt, pszichológiatörténeti érdekességként tartják számon óket, mivel nincsenek mögöttük új sztenderdizálási, validálási vizsgálatok. Ezzel a szemben a projektív tesztek kiválóan alkalmazhatók a gyakorlatban, szinte minden klinikus eszköztárában jelen vannak, és a diagnosztikus folyamat (vagy akár a terápia) részét képezik.

Jelen tanulmányunk célul tûzte ki, hogy áttekinti és összefoglalja a Világjáték-teszt kialakulásának és elterjedésének történetét. A szakirodalmi feldolgozásban hangsúlyosabb szerepet kapott a téma nemzetközi eredményeinek bemutatása, mivel a hazai elméletek széles körben ismertek és elérhetôk. A Világjáték-teszt történetének sajátossága, hogy nincs egységes pszichometriai módszertana, többnyire egymástól független kutatócsoportok vizsgálati eredményeiket önálló tanulmányok formájában publikálták. A teszt születése óta összegzó szándékkal mindössze egy tematikus folyóiratszám (Buhler, Lumry és Carrol: World-test standardisation studies. The Journal of Child Psychiatry, 1951), és egy Bowyer (1970) által szerkesztett tanulmánykötet (The Lowenfeld World Technique. Studies in Personality) jelent meg.

A Világteszt a megszületése utáni évtizedekben számos kutatás és sztenderdizáló vizsgálat tárgya volt, de a tudományos érdeklôdés a témában az 1970-80-as években egyre inkább lecsökkent, és mára szinte meg is szúnt. A korábbi vizsgálatokból kiindulva, és ezek eredményeit figyelembe véve fontosnak tartjuk, hogy olyan feltevéseket fogalmazzunk meg, melyek nem csupán a klinikai gyakorlatban, hanem tudományos, operacionalizálható szinten is relevánssá teszik a Világjáték-teszt használatát.

A Világjáték-teszt sok szempontból hasonlít más projektív módszerekhez, de fontos észrevenni a különbségeket is. Általánosságban a projektív módszerek felületet biztosítanak ahhoz, hogy megfigyeljük az egyénben zajló pszichés történéseket, illetve magát a viselkedést, mely informál a személyiségmúködésrôl és annak funkcionális sajátosságairól. A projektív módszerek az ingerek sajátosságai mentén egy kontinuumon helyezhetốk el. Ennek az egyik végpontját a statikus ingereket felsorakoztató eljárások képviselik (pl. Rorschach, Tematikus Appercepciós Teszt-TAT és Gyermek Appercepciós Teszt - CAT), ezeknél a vizsgálati személy ad jelentést az ingernek. A kontinuum másik végét a rajztesztek jelenítik meg, melyeknél a személy alkotja meg magát az ingert is. Ezek az eljárások nagyobb teret hagynak a kreativitásnak, ami lehetôvé teszi az egyéni narratívák és lelki múködésmódok megjelenését.

A Világjáték-technika ezen két pólus között helyezkedik el. Az eszköz egy szabad projekciós felület, ahol sok apró tárgy biztosítja a vizsgálati személynek, hogy tetszôlegesen építse meg saját világát. A teszt alapját képezô összes tárgy megtalálható a valóságban, ezért az építés alatt a vizsgálati személy kapcsolatba kerül a realitással. A korlátozott tárgykészlet behatárolja a játéktevékenységet, de a fantázia és áttételek útján az épító bármit realizálhat (Mérei, 1974).

A Világjáték biztonságot nyújtó keretrendszerében megjelenhetnek a belsô bizonytalanságok és a feszültségek (hasonlóan pl. a relaxált állapothoz). A feladathelyzet játékká alakul, mely mentes a megítéléstôl, minôsítéstôl. A játék során egy különleges 
világ tárul elénk, ami által láthatóvá válnak a tudatos, a tudatelôttes és a tudatalatti személyiségrétegek sajátosságai, illetve maga a személyiség strukturája (Fischer, 1950).

Mérei (1974) a világtechnika alkalmazásának háromféle módszerét különítette el. Az elsố a Lowenfeld-technika, amelyben a gyermek megépíti a világot, ezt rögzítjük és értelmezzük. A második a Monod-féle változat (forrásmegjelölés nélkül id. Mérei, 1974), amelyben a felépített világot pontosan regisztráljuk, majd az építményhez kiegészítô kérdéseket teszünk fel. Ezek a kérdések teszik lehetôvé a konstrukcióban rejlô projektív áttételek megértését. Polcz Alaine a harmadik változatban, az elkészített konstrukcióban dramatizáló játékot kezd a gyermekkel, így közvetlen utalást kapunk a belsố konfliktusokra. Ezzel a dramatizáló technikával a világjáték túlmegy a diagnosztikai célkitưzésén, és a játék terápiás felhasználását teszi lehetôvé. Maga az eszköz így tér vissza a gyökereihez, Lowenfeld inspirációjához és H. G. Wells padlójátékához (Mérei, 1974).

\section{A VILÁG-TECHNIKA KIALAKULÁSA}

A Világ-technikát mint kutatási (diagnosztikai) és terápiás eszközt elsôként Lowenfeld mutatta be 1937-ben, Párizsban (Bowyer, 1970). Lowenfeld számára H. G. Wells „Játék a padlón" címú írása szolgált inspirációul az eszköz kidolgozásához. Az 1911-ben megjelent könyvben Wells leírta a fiaival játszott tematikus konstrukciós játékokat (Mérei, 1974). Közel két évtizedes klinikai munkája során Lowenfeld ennek alapján finomította, alakította ki a Világ-technikát. Az eszköz „előfutárai” voltak „The Wonder Box” (1925, id. Bowyer, 1970; Lowenfeld, 1939) és „The World” (1927, id. Bowyer, 1970; Lowenfeld, 1939). A párizsi bemutatás után Lowenfeld több kongresszuson és konferencián is bemutatta eseteit. 1938 márciusában, a Medical Section of the British Psychological Societyn tartott előadása volt az alapja az elsố Világ-technikát bemutató publikációnak (Lowenfeld, 1939).

Lowenfeld $(1939,1950)$ szerint a Világ-technika megalkotásának legfontosabb oka és alapja a gyermeki gondolkodás sajátosságainak menete. Megközelítésében a gyermeki gondolkodás nem lineáris, hanem a gondolatok, az érzések, a fogalmak és az emlékezet egymás által átszôtt élményegyüttese. Egy állandóan mozgó folyamat, mely során több szinten egyszerre megjelenô lelki múködés jellemzi élményvilágukat. A gyermeki tapasztalatok érzelmileg összetartozó fürtökben (cluster) reprezentálódnak, és ezek felidézése adja az életben való eligazodás alapját (Mérei, 1974).

A gyermek lelki múködésének kifejezésére, vizsgálatára alkalmas eszköznek egyszerre kell megjeleníteni ezen fürtök különbözô szintjeit, de emellett az egészet (Gestaltot) is (Lowenfeld, 1950). A Világ-technika segítségével a gyermek képes mentális és érzelmi állapotai megjelenítésére, felnôtt értelmezés vagy átvitel nélkül. Az építés során lehetôsége van kifejezni gondolatait és érzéseit, függetlenül elơzetes tudástól vagy készségtôl. A Világjáték lehetôvé teszi az érzelmileg csoportosított tapasztalatok egyidejú reprezentálását, megjeleníti a mozgást, kombinálja az érintés, az érzetek és a látás elemeit. A Világ-technika a lehetô legszabadabb formája a valóság leképezésének, s a létrejött tesztanyag önmagában értelmezhetô, és ezt az értelmezést nem szükséges elméleti kontextusba helyezni (Lowenfeld, 1939). 
Lowenfeld (1950) úgy véli, hogy a klasszikus analitikus gyermek-terapeuta interakció során az derül ki, ahogy a terapeuta gondolkodik a gyermek lelki folyamatairól, míg a Világjáték alkalmazásával a gyermek élményvilága figyelhetô meg. Elméletének központi magja, hogy a játékra úgy tekintett, mint az érzelmek spontán és a szelf által irányított kifejezôdésére. A világ szimbolikus értelmezése nem a terapeuta feladata, annak a gyermek ad jelentést. Lowenfeld kiemeli az objektív megfigyelés fontosságát, és elveti az áttételi folyamatok értelmezésének szükségességét (Hutton, 2004). Értelmezésében úgy kezeli a kapott nyersanyagot, mintha egy kódolt nyelv lenne. Az épített világ tárgyi gazdagságát kiegészíti a hozzá tartozó szótár (Mérei, 1974). A gyermek története, asszociációi nyomán érthetôvé válik az építménye szimbolikája, annak mélységei és az építmény egészének jelentése (Hutton, 2004). A Világ-technika kutatási (diagnosztikai) célja, hogy objektíven tanulmányozzuk a gyermek mentális állapotát - terápiás eszközként pedig az, hogy segítségével megértsük a gyermek konfliktusait (Lowenfeld, 1939; Mérei, 1974).

Lowenfeld elméletének kiindulási alapja a klasszikus analitikus fejlódéslélektan, de nagyon hamar el is határolódik tôle (Hutton, 2004), s ezzel komoly szakmai vitákba kerül (Lowenfeld, 1939). Melanie Klein egyik fô kritikája (Lowenfeld, 1939) ${ }^{1}$, hogy Lowenfeld próbálja magát teljesen elhatárolni és függetleníteni az analitikus elméletektôl, miközben ezen elméletek hatása nyilvánvaló, és nem lehet kijelenteni a Világtechnikáról, hogy mindezektôl független.

A másik kritikus pont, hogy Lowenfeld a tudattalan fogalmától megkülönbözteti a preverbális gondolkodást (proto system thinking) (Hutton, 2004). Úgy véli, hogy a gyermekeknek kezdetben nincs tudattalanjuk, tudatában vannak a tapasztalataiknak, gondolataiknak és érzéseiknek, csak verbális képességeik hiányában nem tudják azokat kifejezni. Ezeket a tapasztalatfürtöket egyes érzékszerveiken, testi mozgásaikon és játékukon keresztül jelenítik meg, és ehhez csak késôbb, a fejlôdés során kapcsolódik a nyelv (Hutton, 2004). Melaine Klein ehhez kapcsolódóan azt állítja (Lowenfeld, 1939), hogy Lowenfeld összekever fogalmakat, jelen idejû tudatos érzésekrôl, gondolatokról beszél, miközben kihagyja a tudattalan fantázia és a korábbi érzelmi tapasztalatok szerepét.

Az eszköz elméleti hátterének több vitás pontja van, melyeknek egy részét már a kortárs szakemberek, más részét az idô is megcáfolta. Azonban a Világ-technika, a Világjáték mint a gyermekek lelki múködését vizsgáló projektív eszköz igen népszerúvé vált. Az 1950-es évektôl Lowenfeld eredeti ötletét sokan „kölcsönvették és adaptálták", amivel párhuzamosan a technika egyre távolabb került az eredeti koncepciótól (Hutton, 2004). Hiányoztak az egységes vizsgálati irányelvek és a megfelelô módszertani és statisztikai eljárások. A különbözô vizsgálatokban még Lowenfeld eredeti eszközének paramétereit is figyelmen kívül hagyták vagy átalakították, melynek az lehet az oka, hogy ebben maga Lowenfeld is elég szabadon, sokszor önmagának ellentmondva fogalmaz.

A vizsgálóeszköz alapja egy fémból készült, $75 \times 52 \times 7 \mathrm{~cm}$, vízálló és rozsdamentes, kívül fekete, belül kék színú tálca, mely az építô derékmagasságában helyezkedik el. Ez lehetôleg két különbözô színú homokkal legyen fedve, mely olyan minôségú, hogy 
kiemelkedô felületeket lehessen képezni belôle (Lowenfeld, 1950). Az elsô írásában (Lowenfeld, 1939) még négy különbözó típusú homokról beszél: tiszta, apró szemcsés, durva barna és ezüstszínú (pl. hó megjelenítéséhez). Minden esetben biztosítani kell az építô számára vizet, hogy kedve szerint formálhassa a homokot (Lowenfeld, 1939, 1950).

Lowenfeld $(1939,1950)$ a tárgyak pontos számát és leírását nem adja meg, mindössze a különbözô kategóriákat írja le: emberek (átlagos emberek - rendôrök is, hadsereg elemei, és speciális figurák), épületek, növények, kerítések, vad- és háziállatok, szállítóeszközök, utcajelek és tartozékok, és vegyes (egyéb) kategória (pl. bútorok, kerti felszerelés és kevésbé meghatározott tárgyak). Fontos, hogy minél több tárgyat szerezzünk be, és ezeket zárható, polcos szekrényben tároljuk. Ne sugalljunk témákat a tárgyak elrendezésével, de jelenjen meg az eszköz gazdagsága és a különbözó reprezentációk lehetôsége.

A Világjáték-teszt felvételekor megmutatjuk a gyermeknek a tálcát, a homokot, a vizet, és annyit mondunk, hogy szabadon csinálhat vele bármit, amit szeretne. Az instrukció során fontos megjegyezni, hogy az építô figyelmen kívül hagyhatja a külsô valóságot. Idôsebb gyerekeknél nincs is szükség instrukcióra, mert magával ragadja ôket a játék vonzósága (Lowenfeld, 1939, 1950).

Az építés alatt pontosan és amilyen részletesen csak lehet, le kell jegyeznünk, hogy az építố milyen tárgyakat használ, mi az ô saját narratívája az építményrôl, milyen asszociációi, reakciói vannak. Az építéssel egy idôben és az építôvel együtt készül a jegyzet, a rajz és az építô saját szavaival történô leírás. A játék során az olyan fogalmak, mint „realitás”, „gravitáció” vagy ,józan ész” fel vannak függesztve. Bármilyen ötlet, akár észszerú, akár nem, elfogadható és lejegyzendő (Lowenfeld, 1950). Lowenfeld felveti, hogy a fényképkészítés lenne a leginkább megfelelő a rögzítésre, és minimum két nézôpontból javasolja a fényképezést, de akkoriban annak bonyolult és költséges volta miatt el is veti ennek rendszeres használatát (Lowenfeld, 1939). Szerencsére, ma már ezt jóval egyszerúbb megoldani.

Az eszköz bemutatásán túl Lowenfeld írásainak nagy hiányossága, hogy egy-egy esetbemutatáson kívül nem ír le tüneti jegyeket vagy bármilyen elôfordulási tendenciát. Többszöri felvétel során néhány gyereknél a zavartság és diszkomfortérzet növekedését leírja, ugyanakkor hangsúlyozza, hogy a világok sorozatos felvétele gyakran összekapcsolódó gondolatokat és belsố logikát jelenít meg. Lowenfeld szerint (1950) az elsô világból csak felületesen tudjuk megérteni a gyermek gondolkodását.

Lowenfeld megfigyelései alapján (Lowenfeldet id. Buhler, 1951a) a Világjátékban lelki problémákat jeleznek az elkerített építményrészek, a vadállatok nem megfeleló módon és helyen való elhelyezése, bizonyos elemek gyakori ismétlése vagy az elemek szokatlan elhelyezése. Lowenfeld kijelenti (különösebb adat és magyarázat nélkül), hogy értelmi fogyatékkal élő ${ }^{2}$ és súlyosan zavart gyerekeknél a teszt nem használható. Fenti megfigyelései mögött azonban nincsenek érvényes vizsgálatok és statisztikai eljárások, ennek pótlására az 1970-es években több kutatócsoport is kísérletet tett.

2 A feldolgozott szakirodalmi szövegekben előforduló korabeli szakmai megfogalmazásokon és diagnózisokon nem változtattunk, a kor- és szöveghű fordítást (ahol lehetett) kiegészítettük a mai szakmai szóhasználattal. 


\section{A VILÁGJÁTÉK SZTENDERDIZÁLÁSA}

Az elsô tudományos igényességgel megtervezett Világjáték sztenderdizáló és összehasonlító vizsgálat az 1930-as években kezdôdött Charlotte Bühler és Margaret van Wylick vezetésével, Bécsben. Ebben a vizsgálatban 50 gyermek vett részt (4-8 év), 333 játékelemet használtak, és játszhattak a tálcán vagy a földön is. Ez a vizsgálat egyfajta „pilot-study” volt, melyet a II. világháború eseményei félbeszakítottak. Fóbb megfigyeléseik ebben a nem kategorizált mintában a játék menetéról (tárgyak manipulálása, játékba vonódás és konstruálás), a játékkal töltött idôrôl (30-135 perc, 5 éves korban a leghosszabb játékidő - átlag 71 perc, 6 éves kortól lecsökken - átlag 50 perc) és a felhasznált elemek számáról (333 elérhetô elembôl a gyerekek 74-146-ot használnak, átlagosan a 6 évesek a legtöbbet) szóltak (Buhler, 1951a).

A világháború után a vizsgálatot folytatták, több országra (Anglia, Norvégia, Hollandia, USA), normál és klinikai gyermekpopulációra (kisebb-nagyobb alkalmazkodási problémákkal küzdő, valamint értelmi fogyatékkal éló gyermekekre) is kibóvítették. A vizsgálatban 174 gyermek vett részt 5 éves kortól 16 éves korig. 30 gyermek képezte a kontrollcsoportot. 117 gyermeknek volt valamilyen jellegú pszichés problémája, ezen túl 27 értelmi fogyatékkal éló gyermek vett részt a vizsgálatban (akkori besorolás szerint IQ 65-90) (Buhler, 1951a).

A vizsgálatban használt Világjáték-teszt összesen 300 elembôl állt. A Lowenfeld-féle leíráshoz képest eltérés volt abban, hogy egyes országokban adtak homokot is az építéshez, más országokban egyszerúen a padlót használták építési felületként. Vizet csak papírral vagy más anyaggal jeleníthettek meg. Az építéshez a gyermekek 20 kategóriából választhattak tárgyakat (háziállatok, vadállatok, templomok, garázsok, istállók, fák, kerítések, bokrok, férfiak, nôk, rendőrök, katonák, autók, lovaskocsik, talicskák, motorbiciklik, ágyúk, versenyautók, csónakok, vonatok, alagutak, hidak) (Buhler, 1951a).

Buhler (1951a) az építményben felhasznált elemek száma és a kihagyott elemek típusai, valamint a tárgyak elrendezésének mintázata (rendezett/rendezetlen, sematikus/realisztikus, szórt/zárt/elkerített) alapján 7 tüneti jegyet különített el (lásd 1. táblázat).

1. táblázat. A Világjáték-tesztben elóforduló tüneti jegyek

\begin{tabular}{|c|c|c|c|c|c|c|}
\hline $50 \mathrm{E}$ & $5 \mathrm{~T}$ & NMW & $\mathrm{A}$ & $\mathrm{C}$ & $\mathrm{R}$ & $\mathrm{D}$ \\
\hline $\begin{array}{l}\text { kevesebb } \\
\text { mint } 50 \\
\text { elem, } \\
\text { nagyon } \\
\text { üres és } \\
\text { kicsi világ }\end{array}$ & $\begin{array}{l}5 \text { vagy } \\
\text { annál } \\
\text { kevesebb } \\
\text { kategória }\end{array}$ & $\begin{array}{l}\text { ember kategó- } \\
\text { ria hiánya } \\
\text { (katona nem } \\
\text { számít a kate- } \\
\text { góriába) }\end{array}$ & \begin{tabular}{|l|} 
agresszív \\
elemek: a \\
katonaság \\
elemei (S \\
- katonák, \\
ágyúk, tan- \\
kok), bal- \\
esetek, gyil- \\
kosságok, \\
vadállatok \\
szabadon
\end{tabular} & $\begin{array}{l}\text { zárt világ, } \\
\text { a világ nagy } \\
\text { része be } \\
\text { van kerítve }\end{array}$ & \begin{tabular}{|l|} 
felsorakoz- \\
tatott, sor- \\
barendezett \\
elemek, \\
eltúlzott \\
elemek
\end{tabular} & $\begin{array}{l}\text { dezorgani- } \\
\text { zált világ, } \\
\text { kaotikusan, } \\
\text { rendszer } \\
\text { nélkül el- } \\
\text { helyezett } \\
\text { elemek }\end{array}$ \\
\hline
\end{tabular}


A tüneti jegyek bármely életkorban megjelenhetnek, de jellemzóen pszichés problémákkal küzdő, illetve értelmi fogyatékkal élô vizsgálati személyeknél nagyobb arányban, és több tüneti jegy fordul elô. Fontos megjegyezni, hogy egyes tünetek különbözô életkori csoportokban differenciáltan jelennek meg. A fiatalabb gyerekek (6 éves kor alatt) gyakrabban kerítenek be dolgokat, kisebb világokat építenek, és szeretnek sorba rendezni. Ebben az életkorban jellemzô az üres építmény (66\%), de ahogy nô az életkor, úgy csökken ez az arány (20-30\%). Szintén jellemzô, hogy fiatalabb gyerekeknél több tüneti jegy is megjelenhet, ez a kor eloorehaladtával szintén csökken (Buhler, 1951a). A tünetek mintázatait és jelentését a 2. táblázat fogalja össze.

2. táblázat. Tüneti mintázatok és jelentésük a Világjáték-tesztben (Buhler, 1951a nyomán)

\begin{tabular}{l|l|l}
\hline Mintázat & Tüneti jegy(ek) & \multicolumn{1}{c}{ Értelmezés } \\
\hline Agresszív világ & A, C, 50E, 5T & $\begin{array}{l}\text { az agresszió projekciója } \\
\text { erôszakosság, egyéni agresszió } \\
\text { (vö. a kor társadalmi hatása) }\end{array}$ \\
\hline Üres világ & $50 \mathrm{E}, 5 \mathrm{~T}, \mathrm{NMW}$ & $\begin{array}{l}\text { elutasítás, menekülés projekciója } \\
\text { ismétlés mint projekció } \\
\text { kapcsolódási deficit }\end{array}$ \\
\hline Szervezetlen világ & $\mathrm{D}, 50 \mathrm{E}$ & gyenge szelf-kontroll, eszköztelenség \\
\hline Sematikus világ & $\mathrm{R}$ & éretlenség, merevség, perfekcionizmus \\
\hline
\end{tabular}

A megfigyelt tüneti jegyek és mintázatok további vizsgálatát és finomítását tûzte ki célul Lumry, szintén 1951-ben publikált tanulmánya. A vizsgálat kifejezett célja volt feltárni, mely jellegzetességek számítanak tünet értékûnek, amelyek elkülönítik a tipikusan fejlôdô gyermekek múködését és különbséget tesznek a különbözô klinikai kategóriák között. A vizsgálati mintát négy 25 fóból álló csoport képezte: tipikusan fejlôdô, dadogó, visszahúzódó és értelmi fogyatékkal élô csoport. A vizsgált gyerekek életkora 6,5-9,5 év között volt, a vizsgálatban 150 elemból álló világjátékot használtak, tálca és homok nélkül (Lumry, 1951).

Az eredmények alapján a tüneti jegyek gyakoriságának növekedése jól elkülöníti a jól alkalmazkodó gyerekeket azoktól, akik valamilyen pszichológiai nehézséggel küzdenek. A tipikusan fejlôdô csoport tagjainál a hét tüneti jegyból maximum egy jelent meg, kettô vagy annál több tünet megjelenése nagy biztonsággal pszichés problémákat jelez. A tünetek száma tehát alkalmas az elkülönítésre, azonban a gyakorisági mutató a problémás csoportokat egymástól nem tudja differenciálni (Lumry, 1951), mely probléma már Buhler (1951a) kutatásában is megjelent.

A adatok elemzéséból kiderült, hogy a különbözô tüneti jegyek jelenthetik a kulcsot a differenciáldiagnózis felállításában, de mindezek csupán tendencia szinten jelentek meg a kutatásban. A tipikusan fejlôdô csoportból egy gyermek sem rakott ki olyan világot, amiból hiányzott az ember kategória, míg a pszichológiai problémával küzdô csoportok 50\%-ában tapasztalható ez a jellegzetesség. Az agresszív tendenciák (A) és a teszt elemeinek limitált használata $(50 \mathrm{E}, 5 \mathrm{~T})$ mutatkozott a legjobb mutatónak a differenciálásban. Az agresszív tartalmak nagyobb mértékben jelentek meg a visszahúzódó és dadogó gyerekeknél. A kevés elem használata relatíve gyakoribb az 
értelmi fogyatékkal élố gyermekeknél, azonban ezek a mintázatok a tipikusan fejlôdô gyermekeknél is tapasztalhatók (Lumry, 1951).

Zárt világ (C) mindegyik csoportban megjelent, de a zárt struktúra önmagában nem feltétlenül implikál pszichológiai nehézséget. A sorba rendezés $(\mathrm{R})$ sokkal tisztább differenciál-diagnosztikai tünet: a tipikusan fejlôdô csoportban egyszer sem fordult elô, az értelmi fogyatékkal éló gyermekek 72\%-a alkalmazta ezt az építési struktúrát. Hasonló differenciáló hatása van a kaotikus, dezorganizált mintázatnak, mely 56\%-ban jelent meg az értelmi fogyatékkal éló gyermekek csoportjában (Lumry, 1951).

Lumry (1951) vizsgálatában statisztikailag két csoportot lehetett elkülöníteni. Az agresszív történések (A) és a dezorganizáció (D) a visszahúzódó gyerekeknél, az ember kategória hiánya kevés elemszámmal (NMW, 5T, 50E) pedig az értelmi fogyatékkal élô gyermekeknél volt gyakoribb. Az eredményei nyomán Lumry (1951) kiemeli, hogy egy-egy tünet nem alkalmas differenciálásra, sokkal inkább a tünetek kombinációja, bizonyos mintázatok megjelenése lehet diagnosztikus értékú.

Buhler és Carrol (1951) következô vizsgálatában 30 gyerek vett részt, 5. osztályosok (angol-szász iskolarendszerben, életkori megjelölés nélkül), eltérô szocioökonómiai státussal, a szociális alkalmazkodás és belsô lelki egyensúly alapján tanári szakvélemények alapján kategorizálva. Egy hónapon belül minden gyermekkel két világjáték felvételére került sor. Az összesen 60 építmény elemzése alapján a tipikus mintázaton kívül három jellegzetes mintázat alakult ki (3. táblázat).

Az agresszív/veszélyes mintázat nem különíti el a csoportokat, közel azonos arányban fordul elô az elsó építményekben, és ez az előfordulási arány növekedett a második alkalommal. Az agresszív vágyak vagy félelemek kifejezôdése a gyermekeknél általános szükségletként mutatkozik (Buhler és Carrol, 1951). A veszélyes világ mintázat egészséges agressziót jelez, többnyire az időszakosan jelen lévô felszínes nehézségeket

3. táblázat. Tüneti mintázatok a Világjáték-tesztben (Buhler és Carrol, 1951)

\begin{tabular}{|c|c|c|}
\hline \multicolumn{3}{|c|}{ Veszélyes világ (A) } \\
\hline Balesetek & Harc & Vadállatok \\
\hline $\begin{array}{l}\text { tûz, karambol, gyilkosság, } \\
\text { temetés, rablás }\end{array}$ & katonák (S) harcolnak & vadállatok jelenléte, harapása \\
\hline \multicolumn{3}{|c|}{ Üres világ (E) } \\
\hline Emberek hiánya $(N M W)$ & 50 elem alatt (5OE) & 5 kategória alatt (5T) \\
\hline $\begin{array}{l}\text { nincs emberfigura vagy csak } \\
\text { gyerekek, vagy csak katonák } \\
\text { és rendốrök }\end{array}$ & $\begin{array}{l}\text { a felhasznált elemek száma } \\
\text { kevesebb mint } 50\end{array}$ & $\begin{array}{l}\text { a felhasznált kategóriák szá- } \\
\text { ma kevesebb mint } 5\end{array}$ \\
\hline \multicolumn{3}{|c|}{ Zavart világ (CDR) } \\
\hline Zárt (C) & Dezorganizált $(D)$ & Rigid $(R)$ \\
\hline $\begin{array}{l}\text { sok kicsi, elzárt terület, rész- } \\
\text { ben vagy teljesen körbezárt, } \\
\text { körbekerített világ }\end{array}$ & $\begin{array}{l}\text { elemek oda nem illố helye- } \\
\text { ken, kapcsolat nélküli egysé- } \\
\text { gek, elemek vagy csoportok } \\
\text { kaotikus elrendezése }\end{array}$ & $\begin{array}{l}\text { sematikus elrendezés, állatok } \\
\text { vagy emberek sorba rende- } \\
\text { zése }\end{array}$ \\
\hline
\end{tabular}


jelenítik meg a gyermekek ebben a formában. Az építményekben megjelenô balesetek jelenléte viszont mélyebb érzelmi zavarra utalhat (Buhler, 1951c).

Buhler és Carrol (1951) kutatásában az üres mintázat túl alacsony számban fordult elố ahhoz, hogy abból szignifikáns következtetéseket vonjunk le. Az üres világ egyfajta leblokkolásra, intellektuális vagy érzelmi sivárságra utal. Buhler és Carrol (1951) megállapították, hogy azokra a gyermekre volt jellemzô ez a mintázat, akik egyedüllétre vágytak vagy magányosak, gátoltak voltak, és ez megakadályozta, hogy kihasználják a játék lehetôségeit.

Az üres mintázat tünetei több módon is értelmezhetook. Az 5 évnél fiatalabb gyerekek tipikus múködését mutatják be: egocentrikus, védett világ, leegyszerúsített elrendezés, kevés elem nem valóságos helyeken (lásd következó fejezet). Az üres mintázat bármely más életkorban értelmi elmaradást jelez, mert a fantázia hiányát jelentheti. Az emberek hiánya jelezheti az emberekhez való ellenséges viszonyulást vagy bizonytalanságot. Felnôttek hiánya és kizárólag gyermekek jelenléte pedig bizonyos életkor felett regresszív múködést valószínúsít. Katonák és rendôrök kizárólagos jelenléte rejtett agresszióra utal (Buhler, 1951c).

A zavart mintázat jellemzôi a valóságtól elrugaszkodott, különös mintázatú, rigid, kaotikus építmények. A zárt világ magát a védelmet implikálja fokozott bizonytalanság vagy önvédelem esetén, az érzelmek elrejtésének eszközeként. A dezorganizált világban a realitáshoz viszonyítva megszakadás vagy zavarodottság jelenik meg. A zavarodottság a dezorganizáció fokához, a gyermek életkorához vagy a személyiségstruktúra fellazultságának fokához viszonyítva erôs tüneti jegy lehet. A rigid elrendezés kényszeres tendenciát és perfekcionizmust implikál (Buhler és Carrol, 1951).

Leginkább a zavart mintázat mutatja meg a lelki múködés deficitjeit: szorongás, zavarodottság, sóvárgás, vagy rémülettel átitatott gondolkodás. A világok minôségi elemzése nyomán elmondható, hogy mély érzelmi problémákat jelzô kritérium a két vagy több tüneti jegy jelenléte, melyben mindenképpen megtalálhatók CDR jegyek. A tipikusan fejlôdó gyermekek csoportjában egy tüneti jegynél nem volt több, nem volt jellemzô a dezorganizáltság (D) és az ember kategória hiánya (Buhler és Carrol, 1951). Ezek alapján a CDR jegyeket a mély érzelmi zavarok szignifikáns jegyeiként azonosították, különbözó pszichés betegségek tünetei lehetnek a neurózisoktól a pszichózisokig (Buhler, 1951c).

Összefoglalva a Charlotte Buhler munkacsoportjához tartozó sztenderizáló vizsgálatokban (Buhler, 1951b) összesen 304 fơvel történt vizsgálat, 4 éves kortól 16 éves korig. Az összesített vizsgálati mintában 65 fố volt jól alkalmazkodó (tipikusan fejlôdô), 52 fố volt értelmi fogyatékkal élô és 187 fô küzdött minor vagy major problémával az alkalmazkodás terén. A vizsgálati eredményeket összefoglalva Buhler arra a következtetésre jutott, hogy a Világjáték-teszt gyors és objektív projektív technika, illetve diagnosztikus eszköz, amely információt adhat számunkra az épító érettségi szintjérôl, és általa értelmezhetôvé válnak érzelmi nehézségek, agresszív tendenciák, valamint mélyebb pszichés problémák, mint például szorongás vagy zavarodottság (Buhler, 1951b).

Buhler (1951b) kiemeli, hogy a Világjáték hasznos információt ad azáltal, ahogy megragadja a fejlôdési aspektust. A fejlódési jellegzetességeket azonban nem kutatta, összefoglalóan általános mintázatokat ír le (Buhler, 1951b). Más kutatók Buhlerék 
sztenderdizálása nyomán a Világjátékban tapasztalható jellegzetes életkori jegyeket igyekeztek megragadni.

A Világjáték-teszt sztenderdizálási vizsgálatainak paramétereit és legfontosabb eredményeit a 4. táblázatban foglaltuk össze.

4. táblázat. A Világjáték-teszt sztenderdizálási vizsgálatai

\begin{tabular}{|c|c|c|c|}
\hline \multicolumn{4}{|c|}{ A Világjáték-teszt sztenderdizálási vizsgálatainak összefoglalása } \\
\hline Kutató (évszám) & $\begin{array}{l}\text { Eszköz, elemek és } \\
\text { kategóriák száma }\end{array}$ & $\begin{array}{l}\text { Vizsgálati személyek } \\
\text { és korcsoportok }\end{array}$ & Tüneti jegyek \\
\hline Lowenfeld $(1939,1950)$ & $\begin{array}{l}\text { Tálca, többféle } \\
\text { homok, víz, } \\
\text { 300-400 elem, } 6 \text { vagy } \\
8 \text { kategória }\end{array}$ & \multicolumn{2}{|c|}{$\begin{array}{l}\text { nincsenek átfogó, összegzô vizsgálatok, eset- } \\
\text { tanulmányok leírása, } \\
\text { a módszer bemutatása }\end{array}$} \\
\hline $\begin{array}{l}\text { Buhler és van Wylick } \\
\text { (1935-tôl) } \\
\text { "pilot-study" } \\
\text { (önállóan nem } \\
\text { publikált, félbeszakadt } \\
\text { vizsgálat) }\end{array}$ & $\begin{array}{l}\text { tálca vagy föld } \\
333 \text { elem } \\
\text { (víz nincs) }\end{array}$ & $\begin{array}{l}50 \text { gyerek 4-8 éves } \\
\text { kor között } \\
\text { (nem kategorizált } \\
\text { minta) }\end{array}$ & $\begin{array}{l}\text { nincsenek tüneti je- } \\
\text { gyek megfogalmazva } \\
\text { - a játék menetének } \\
\text { leírása } \\
\text { - átlagosan felhasz- } \\
\text { nált elemek száma } \\
\text { - átlagos építési idố }\end{array}$ \\
\hline Buhler (1951) & $\begin{array}{l}\text { Homok vagy földön } \\
\text { építés, } 300 \text { elem, } 20 \\
\text { kategória (tálca, víz } \\
\text { nincs) }\end{array}$ & $\begin{array}{l}174 \text { gyerek 5-16 éves } \\
\text { kor között } \\
30 \text { sine morbo és } 117 \\
\text { pszichés problémával } \\
\text { küzdő és } 27 \text { értelmi } \\
\text { fogyatékos }\end{array}$ & $\begin{array}{l}7 \text { tüneti jegy: 50E, } \\
\text { 5T, NMW, S, A, C, R } \\
\text { és D mintázat }\end{array}$ \\
\hline Lumry (1951) & $\begin{array}{l}\text { Földön építés } \\
150 \text { elem } \\
\text { (tálca, homok, víz } \\
\text { nincs) }\end{array}$ & $\begin{array}{l}100 \text { gyerek 6,5-9,5 } \\
\text { éves kor között } \\
\text { normál, dadogó, } \\
\text { visszahúzódó és ér- } \\
\text { telmileg elmaradott } \\
\text { 25-25 fôs csoportok }\end{array}$ & $\begin{array}{l}\text { - tünetek száma al- } \\
\text { kalmas az elkülöní- } \\
\text { tésre } \\
\text { - kettố vagy annál } \\
\text { több tünet meg- } \\
\text { jelenése nagy biz- } \\
\text { tonsággal pszichés } \\
\text { problémákat jelez } \\
\text { - visszahúzódó gyere- } \\
\text { kek: A, D } \\
\text { - értelmi fogyatékos } \\
\text { gyerekek: NMW, } \\
\text { 50E, 5T } \\
\end{array}$ \\
\hline Buhler és Carrol (1951) & $\begin{array}{l}30,5 x 30,5 \mathrm{~cm} \\
\text { négyzetben a földön } \\
\text { építés, } \\
160 \text { elemes készlet, } \\
10 \text { kategória } \\
\text { (tálca, homok, víz } \\
\text { nincs) }\end{array}$ & $\begin{array}{l}30 \text { gyerek (5. osz- } \\
\text { tály), eltérố SOS }\end{array}$ & $\begin{array}{l}3 \text { mintázat: A, E, } \\
\text { CDR }\end{array}$ \\
\hline
\end{tabular}




\section{ÉLETKORI JELLEGZETESSÉGEK A VILÁGJÁTÉKBAN}

Több olyan vizsgálat is készült, mely célul túzte ki a Világjátékban a gyermekkori jellegzetességek feltárását, de igazán átfogó fejlôdési koncepció csak két vizsgálatban jelent meg: Kamp és Kessler, valamint Bowyer 1970-ben publikált munkáiban. Más vizsgálatokban a hangsúly a klinikai jellegzetességekre tolódott, és kevéssé tudtak hozzáadni Buhlerék eredményeihez. ${ }^{3}$ A továbbiakban ennek a két vizsgálatnak az eredményeit ismertetjük.

A Világjáték mint fejlôdési skála elsô vizsgálata Kamp és Kessler nevéhez füződik, akik 1948 óta kutattak a témában (Bowyer, 1970). 1970-ben publikált vizsgálatukban 80 gyerek vett részt, 20-20 fős 6-9 éves kor közötti életkori csoportokban. Vizsgálati elrendezésükben a vizsgálati személyek egy speciális, egyik végén lekerekített, téglalap alakú asztalon („vasalódeszka”) építették a világot. A Világjátékot kiegészítették Stanford-Binet, Rorschach, csökkentett számú TAT kép és Goodenough emberrajzzal is (Kamp és Kessler, 1970).

Kamp és Kessler által meghatározott fejlôdési skála a Világjátékban mutatott jellegzetességek alapján 3 éves kor felett különböztet meg négyféle konfigurációt, építménytípust. 3 éves kor alatt a gyermek építménye kaotikusnak tûnhet, a gyermek a tárgyakat jellemzôen válogatás nélkül ragadja meg, nevezi meg ôket, és random módon helyezi el (Kamp és Kessler, 1970).

Az építés négy kategóriája összefügg a biológiai és a mentális életkorral. Minél érettebb és/vagy intelligensebb egy gyermek, annál magasabb szintû világot épít. Az életkor elôrehaladtával egyre magasabb szintú építmények készülnek, különösen nagy a változás 7 és 8 éves kor között. Kamp és Kessler (1970) a kategóriákat az 5. táblázatban látható módon különítette el. A konfigurációk az életkorral változnak, de nem válnak el élesen egymástól, sokszor tapasztalható átmenet. Például 7 éves korban a

5. táblázat. Fejlôdési konfigurációk Világjáték-teszt alapján

(Kamp és Kessler, 1970; Bowyer, 1970)

\begin{tabular}{|c|c|c|c|}
\hline $\begin{array}{l}\text { Juxtapozícionális } \\
\text { konfiguráció }(\mathrm{J})\end{array}$ & Sematikus konfiguráció (S) & $\begin{array}{l}\text { Leíró } \\
\text { konfiguráció }(\mathrm{D})\end{array}$ & $\begin{array}{l}\text { Realisztikus } \\
\text { konfiguráció }(\mathrm{R})\end{array}$ \\
\hline 4-5 éves kor & 6-7 éves kor & 8-9 éves kor & 10 éves kor felett \\
\hline $\begin{array}{l}\text { szelektált tárgy- } \\
\text { választás }\end{array}$ & $\begin{array}{l}\text { egy vagy két különböző } \\
\text { kategória elemeinek kom- } \\
\text { binálása }\end{array}$ & \multicolumn{2}{|c|}{ több mint két kategória elemei } \\
\hline $\begin{array}{l}\text { a tárgyak sorba renc } \\
\text { elszórása }\end{array}$ & lezése vagy diffúz módon & $\begin{array}{l}\text { a mintázat nem } \\
\text { mindig reális, az } \\
\text { elrendezés sok- } \\
\text { szor diffúz }\end{array}$ & $\begin{array}{l}\text { „magasabb Gestalt } \\
\text { minôség” } \\
\text { a tárgyak funkciói } \\
\text { és elrendezésük is } \\
\text { megfelel a valóságnak }\end{array}$ \\
\hline $\begin{array}{l}\text { nem konvencioná- } \\
\text { lis heterogenitás: } \\
\text { a tárgyak jelentése } \\
\text { nem függ össze az } \\
\text { elhelyezésükkel }\end{array}$ & \multicolumn{3}{|c|}{$\begin{array}{l}\text { a tárgyak téri elrendezése kifejezi, hogy azok összetartoznak, kapcsolatot } \\
\text { jelenít meg közöttük }\end{array}$} \\
\hline
\end{tabular}

Bowyer 1970-es összefoglaló könyve ismerteti ezen vizsgálatokat, mi ezekre nem térünk ki. 
sematikus konfiguráció az uralkodó, de szórványosan elófordulnak alacsonyabb (J) és magasabb (D) szerkezetú világok is.

Bowyer 1956-os vizsgálatának (melyet 1970-ben publikált könyvében) célja, hogy a Világjáték segítségével fejlődési normákat írjon le, melyekhez képest értelmezni tudjuk a klinikai eltéréseket. 76 fős vizsgálatában 50 gyermek (2-17 év közötti) vett részt, melybôl 26 fô alkotta a tipikusan fejlôdô csoportot. Minden résztvevô esetében három világ építésére került sor. Az értelmezésnél a következô területeteket vizsgálta: felhasznált terület, homokhasználat, agresszió, kontroll, tartalom és idôi perspektíva. Bowyer (1970) eredményei alapján a 6. táblázatban összefoglaljuk az tipikusan fejlôdô gyermekek életkori jellegzetességeit. Fontos kiemelni, hogy ezen jellegzetességek az adott életkorokban egészséges lelki múködést jeleznek, attól eltéróen viszont enyhébb esetekben is regressziót vagy sokszor klinikai tüneteket valószínúsítenek.

A Világjáték felnôtt korra érvényes adaptációját Bolgar és Fischer (Bolgar és Fischer, 1947; Fischer, 1950) fejlesztette ki, és validálta. Bolgar és Fischer (1947) 100 személy (50 nô, 50 férfi, 18 és 70 év között) részvételével alakította ki a norma értékeit. A résztvevốk nem álltak neurológiai vagy pszichiátriai kezelés alatt. A vizsgálatban használt eszköz 232 darabos Világteszt volt, az elemeket 15 kategóriába osztották el (pl. házak, kerítések, fák, emberek, egyenruhások, katonák, kutya, haszonállatok, vadállatok, hidak, közlekedési eszközök, szolgáltatások stb.). Az építéshez egy asztalt, illetve a padlót használták. Fischer (1950) késôbb differenciáldiagnosztikai szempontból próbálta a különbözôségeket, illetve hasonlóságokat megtalálni a különbözô betegcsoportok között (24 fôs kontrollcsoport; 69 fó pszichiátriai vagy neurológiai kezelés alatt álló beteg).

A tesztek értékelése szempontjából 6 jellegzetességet vettek figyelembe: (1) elsô tárgyválasztás, vagyis az építés során használt elsô tárgy, amely befolyásolja a késôbbi konstrukciót (leggyakoribb a ház és a híd), (2) mennyiségi mutatók (felhasznált elemek és kategóriák száma), (3) formai jegyek, a felépített struktúra sajátosságai, (4) viselkedés a világ építése során, (5) verbalizáció az építés közben, illetve a világ explorációs leírása és végül a (6) tartalmi elemzés (Bolgar és Fischer, 1947). A személyiség szervezôdése, jellegzetességei a 7. táblázat tartalmi struktúrái alapján differenciálható.

A fenti szempontok alapján Bolgar és Fischer (1947) egy intervallumrendszert dolgozott ki. Az intervallumok a normál eloszláshoz hasonlóan rendelkeztek egy átlag alatti, egy átlagos és egy átlag feletti tartománnyal. A két szélsố tartományt „deviációs” résznek nevezték el, az átlagos tartományt pedig „normál” övezetnek. Az egészséges személyiséget egyaránt alakítják „normál” és „deviáns” konstellációk is, azonban a túlzott eltolódás az egyik vagy másik „deviáns” irányba pszichés problémára utalhat (Bolgar és Fischer, 1947).

Bolgar és Fischer megközelítésében (1947) a pszichopatológia szemszögébôl a valóságérzékelés kulcsfontossággal bír. A vizsgálati mintában nagyon kevés világ képezte le teljesen a valóságot, illetve az is ritkán fordult elô, hogy teljesen a fantázia uralja az építményt, és ne jelenjen meg a realitás semmilyen formában.

Bowyer (1970) vizsgálati eredményeinél láttuk, hogy 10-12 éves korra alakul ki stabilan az a mentális képesség, hogy a Világjátékban a miniatürizált tárgyakat a valósághoz kapcsoljuk. Bolgar és Fischer (1947) szerint a személyiség múködésének egyfajta 
6. táblázat. Életkori jellegzetességek gyermekkorban a Világjáték-teszt alapján (Bowyer, 1970)

\begin{tabular}{|c|c|c|c|c|c|}
\hline & 2-3 éves & 4-5 éves & 6-7 éves & 8-10 éves & 11 év felett \\
\hline $\begin{array}{l}\text { Felhasznált te- } \\
\text { rület }\end{array}$ & $\begin{array}{l}\text { vízszintes perem } \\
\text { vagy vízszintes } \\
\text { perem és sarok } \\
\text { menti elhelyezés } \\
\text { (jellemzóen bal } \\
\text { sarok) } \\
\text { jellemzó a tálcán } \\
\text { kívüli játék }\end{array}$ & $\begin{array}{l}\text { a tálca területé- } \\
\text { nek felhasználá- } \\
\text { sa növekszik }\end{array}$ & \multicolumn{3}{|c|}{$\begin{array}{l}\text { a tálca teljes területének, mind a négy } \\
\text { oldalának használata (nagy egyéni } \\
\text { különbségekkel) }\end{array}$} \\
\hline $\begin{array}{l}\text { Homok- } \\
\text { használat }\end{array}$ & $\begin{array}{l}\text { a homok dest- } \\
\text { ruktív használata: } \\
\text { szórás, tárgyak } \\
\text { belenyomása, el- } \\
\text { temetése }\end{array}$ & $\begin{array}{l}\text { legkevésbé jel- } \\
\text { lemzó a homok- } \\
\text { használat } \\
\text { (ha van, akkor } \\
\text { egyre inkább } \\
\text { konstruktív) }\end{array}$ & \multicolumn{3}{|c|}{$\begin{array}{l}\text { konstruktív homokhasználat } \\
\text { (hegyek, völgyek, utak, csatornák } \\
\text { stb.) }\end{array}$} \\
\hline Agresszív jegyek & $\begin{array}{l}\text { tárgyak dobálása, } \\
\text { homok szórása } \\
\text { vagy teljes elteme- } \\
\text { tése }\end{array}$ & \multicolumn{2}{|c|}{$\begin{array}{l}\text { „drámai hatások” } \\
\text { jármúhangok, jármúvek } \\
\text { erôteljes mozgatása, tárgyak } \\
\text { ütögetése a tálcához, embe- } \\
\text { rek beszórása homokkal }\end{array}$} & $\begin{array}{l}\text { szem- } \\
\text { benálló } \\
\text { felek (pl. } \\
\text { cowboy- } \\
\text { indián) } \\
\text { harca }\end{array}$ & $\begin{array}{l}\text { autós üldözé- } \\
\text { sek, vadálla- } \\
\text { tok támadása }\end{array}$ \\
\hline Kontroll & $\begin{array}{l}\text { nincs kontroll, } \\
\text { kaotikus építmé- } \\
\text { nyek }\end{array}$ & $\begin{array}{l}\text { több kohe- } \\
\text { rens részlet, de } \\
\text { sokszor nem } \\
\text { differenciált } \\
\text { tárgyakkal }\end{array}$ & \multicolumn{2}{|c|}{$\begin{array}{l}\text { egyre több kerítés - } \\
\text { eleinte még kapuk } \\
\text { nélkül }\end{array}$} & \begin{tabular}{|l} 
szervezett \\
mintázatok \\
egymáshoz \\
kapcsolódó \\
részletekkel, \\
tartalmi és \\
szimbolikus \\
kontroll \\
\end{tabular} \\
\hline $\begin{array}{l}\text { Tartalom } \\
\text { (emberek és } \\
\text { állatok minden } \\
\text { életkorban } \\
\text { megjelennek) }\end{array}$ & \multicolumn{2}{|c|}{$\begin{array}{l}\text { a tárgyak egymástól függetlenül je- } \\
\text { lennek meg, jellemzó a sok állat, } \\
\text { épület nagyon ritka, } \\
\text { gyakoriak az étellel, etetéssel, ét- } \\
\text { kezéssel kapcsolatos tartalmak }\end{array}$} & \begin{tabular}{|l} 
alacsony \\
szintú \\
egységek \\
(pl. autó \\
garázzsal, \\
tehén bor- \\
jakkal), \\
sok állat, \\
farmje- \\
lenetek, \\
szállítás
\end{tabular} & $\begin{array}{l}\text { közepes } \\
\text { szintú egy- } \\
\text { ségek (egy } \\
\text { jelenet, pl. } \\
\text { város vagy } \\
\text { falu) } \\
\text { sok fa, egy- } \\
\text { re inkább } \\
\text { elótérbe } \\
\text { kerül a } \\
\text { valóság le- } \\
\text { képezése }\end{array}$ & $\begin{array}{l}\text { egészleges } \\
\text { (Gestalt) tar- } \\
\text { talom, magas } \\
\text { szintû, } \\
\text { kapcsolódó } \\
\text { egységekkel }\end{array}$ \\
\hline Idô-perspektíva & \multicolumn{2}{|c|}{$\begin{array}{l}\text { jelenhez kapcsolódó tárgyválasztás: } \\
\text { ami tetszik neki, felhasználja }\end{array}$} & $\begin{array}{l}\text { tárgyakhoz } \\
\text { kapcsoló- } \\
\text { dóan meg- } \\
\text { jelennek } \\
\text { korábbi } \\
\text { élmények }\end{array}$ & \multicolumn{2}{|c|}{$\begin{array}{l}\text { kigondolt történethez } \\
\text { keres tárgyat, } \\
\text { előretervezés }\end{array}$} \\
\hline
\end{tabular}


7. táblázat. Tartalmi struktúrák felnôttek Világjáték-tesztjében (Bolgar és Fischer, 1947)

\begin{tabular}{|c|c|c|c|c|}
\hline P (praktikus) & L (logikus) & S (szociális) & V (vitális) & E (esztétikus) \\
\hline $\begin{array}{l}\text { Praktikus, illetve } \\
\text { konkrét gyakor- } \\
\text { lati problémák } \\
\text { pl. egy ház opti- } \\
\text { mális berende- } \\
\text { zése }\end{array}$ & $\begin{array}{l}\text { Absztrakt struk- } \\
\text { túrák, illetve az } \\
\text { azok közötti kap- } \\
\text { csolat } \\
\text { pl. autók és utak } \\
\text { kölcsönhatása }\end{array}$ & $\begin{array}{l}\text { Elsôsorban társa- } \\
\text { dalmi szervezet } \\
\text { vagy közösség }\end{array}$ & \begin{tabular}{|l} 
Természet, az \\
emberek és az \\
állatok ösztönös, \\
létfontosságú \\
igényei, örömei, \\
vágyai
\end{tabular} & $\begin{array}{l}\text { Az esztétikum } \\
\text { elsốdlegessége } \\
\text { (stílus, forma és } \\
\text { színhatás) }\end{array}$ \\
\hline
\end{tabular}

mércéje, hogy a Világjátékban hogyan és milyen formában jelenik meg a realitás. Fischer (1950) szerint az építmény képet ad arról, hogy milyen a realitáshoz való viszony, az építố hogyan ragadja meg a valóságot. A megfelelő „világkép”, vagyis az optimális realitásérzékelés mutatja a külvilághoz való megfelelô alkalmazkodást.

12 éves kor felett az építményben megjelenô zavarok jelzik a realitás érzékelésének zavarát, ami rossz alkalmazkodási készséget, illetve pszichés problémát valószínúsít. Fischer (1950) azt tapasztalta, hogy a klinikai csoport Világjátékaiban gyengébb a realitással való kapcsolat, illetve a deviációs mintázat túlsúlya rajzolódik ki. A realitáshoz való viszony az egészséges csoportnál optimális, a neurotikusoknál mutatkozik kisebb eltérés a normál tartományon belül, a legkevésbé realiszitikus viszony jellemzi a mániás, a „pszichotikus” és az értelmi fogyatékkal élók építményeit. Utóbbi esetekben gyakran tapasztalható dezorganizáció és lineáris építés, ezek sajátosságai klinikai csoportonként változtak. A felnôtt építmények klinikai jellegzetességei hasonló képet mutatnak, mint Buhler munkacsoportjának (1951a; Buhler és Carrol, 1951) eredményei a gyermekkori sztenderdizációs vizsgálatokban.

\section{A VILÁGJÁTÉK-TESZT HAZAI VONATKOZÁSAI - FELHÍVÓ KÉRDÉSEK ÉS SZIMBÓLUMOK}

A Világjáték-teszt hazai adaptációjának úttörője Polcz Alaine volt, aki nem csupán hazai mintán „alkalmazta” a tesztet, hanem annak újszerú értelmezésével is tovább gazdagította diagnosztikai és terápiás értékét. Polcz (1966) a világépítés befejezését követốn felhívó jellegú kérdéseket tett fel, mellyel meghatározta a vizsgálat irányát. A kisegítô kérdések segítenek abban, hogy apró részletek is a felszínre tudjanak kerülni, és meg tudjuk világítani a játékban megfogalmazódó konfliktust. A projekciós tér megelevenítésével nemcsak a probléma válik láthatóvá, hanem konkrét helyzetre is kapunk utalást. Minél fiatalabb a gyermek, annál szorosabban fonódik össze a szimbólum és a konkrétum, tehát minél kisebb a gyermek, a kérdéseinkre annál világosabb, „ôszintébb” választ fog adni (Polcz, 1966).

Polcz (1966) kiemeli, hogy a felhívó kérdések terápiás hatásúak is lehetnek. A gyermek vagy a felnőtt áttételek útján fejezi ki nehézségeit, a kérdésekkel egyre pontosabbá tesszük ezek „megfogalmazását”, ezzel az egyént önmaga élményszerú megismeréséhez segítjük hozzá. A játékban megelevenített konfliktus terápiás haszna, hogy lehetôvé teszi a szemléletes úton történô konfrontálást az egyénnel, a környezetével, a családtagokkal. Más szemszögbool olyan tartalmak válhatnak a játék során felismerhe- 
tôvé, amelyek korábban nem voltak világosak (tudatosak ${ }^{4}$ ), illetve elhárítás alatt voltak (Polcz, 1966).

A személyiség strukturális jegyeit, a traumatikus élményeket az építmény és az exploráció tárja fel, sôt még a miliố ártalmaira nézve is utalásokat tartalmaz. Polcz (1966) szerint a kötődéshez és az énazonosításhoz kapcsolódó problémák a felhívó kérdések segítségével jeleníthetôk meg leginkább. A kapcsolatok minôségi elemzése szempontjából fontos diagnosztikai támpontok jelennek meg az egyéni, és a családtagok közötti viszonyok szempontjából, illetve az egymáshoz és a gyermekhez való viszonyról (ahogy azt a gyermek megéli). E mellett a gyermek önmagával való kapcsolatát, az énazonosítás problematikáját is teljesebben körbe tudjuk járni (Polcz, 1966).

Késôbb Polcz (1999) bóvítette a felhívó kérdésekkel feltárható konfliktusokat, így megjeleníthetôvé váltak azok a területek, amelyek érzelmileg pozitívak, negatívak, vagy amelyek valamilyen veszélyre hívják fel a figyelmet. A Polcz (1999) szerint diagnosztikus és terápiás szempontból releváns felhívó kérdéseket a 8. táblázatban mutatjuk be. ${ }^{5}$

8. táblázat. Felhívó kérdések és elôhívott konfliktusok a Világjáték-tesztben (Polcz, 1966, 1999)

\begin{tabular}{l|l}
\hline Felhívó kérdés & Felhívó jelleg \\
\hline Hol laksz te itt ebben a világban? & $\begin{array}{l}\text { Az egyén és a családtagok kötődési minôsége, illetve az } \\
\text { egymáshoz és a gyermekhez való viszony }\end{array}$ \\
\cline { 1 - 2 } Kivel laksz itt ebben a világban? & Énazonosítás \\
\hline Ki vagy te itt ebben a világban? & $\begin{array}{l}\text { Érzelmileg pozitívan és negatívan hangsúlyozott terüle- } \\
\text { tek }\end{array}$ \\
\hline Hol süt a nap és hol van árnyék? ki a tûz? & $\begin{array}{l}\text { A veszélyeztetett zónák, pontok, problémák, helyek, } \\
\text { és helyzetek. Ez irányulhat a jelenre, a múltra és a } \\
\text { jövoóre }\end{array}$ \\
\hline
\end{tabular}

A világról alkotott történettel, és a felhívó kérdésekkel eljutunk abba a pszichés mélységbe, amit Polcz (1966) az álom nyelvének nevezett. Itt lehetôségünk van belépni egy dramatikus játékba, mintha a tudat kettôs nyelvén, vagyis az álomban maradnánk. A korábbi passzív szakasz, ahol kirajzolódott a probléma, aktívvá válik. A játékkal élményt nyújtunk, ahol a sajátoshoz és a pillanatnyihoz is alkalmazkodni tudunk, ami segíti az építôt a pszichés átdolgozásban és a megfelelô problémamegoldás kialakításában.

A Világjáték-teszt hazai történetében fontos kiemelnünk Frenkl Sylvia munkáját, aki a Világjáték diagnosztikai- és terápiás értelmezését szimbolikus megközelítésben gondolta tovább. Frenkl (1987) kiemeli, hogy az instrukcióval megváltoztatjuk a kliens realitáshoz való kapcsolatát, kettôs tudatot hozunk létre, játszani hívjuk, amivel egyfajta regressziót kívánunk létrehozni (Frenkl, 1987). Így a megépített világnak sajátos

\footnotetext{
A „tudatos” jelzố a szerzốk értelmezése, Polcz minden írásában kerülte ezt a fogalmat.

További felhívó kérdések is jellemzôek a gyakorlati munkában (pl. Harangoznak - miért? Levelet hoz a postás - kinek, mi van benne? Valami nagyon jó történik ebben a világban - Mi az? Valami nagyon rossz történik ebben a világban - Mi az?), de Polcz (1999) ezeket kevésbé fontos kérdéseknek tartotta, nem is használta fel az építmények elemzésekor.
} 
kifejezése van, mintha kettôs nyelven kommunikálnának velünk: a tudat nyelvén a konkrétumokról és a tudatalattién pedig az álom szintjén. A játék felszólításával, miszerint „Építsd fel a tengerben a szárazföldet”, valami nagyon ôsire utalunk, olyanra, ami Freud szerint a tudateloottesben, Jung szerint a kollektív tudattalanban mindanynyiunkban jelen van (id. Frenkl, 1987).

A konstrukcióban nemcsak önmagunk kifejezôdése válik láthatóvá, hanem az is, hogy milyen kapcsolatunk van a természettel és a környezettel. A tálca kerete fontos tényezôvé válik az építés során, mivel egyfajta határt szab a játszó fantáziájának, és így rendezô-védô tényezôként is hat. Sok esetben a játékban megjelenô szimbólumokat, illetve azok projekciós lehetôségeit használjuk fel a tudattalan megértéséhez (Frenkl, 1987). Piaget szerint a szimbólum érzelmeket, konkrét élményeket szólaltat meg affektív nyelven, szemben az intellektuális beszéddel, amely a személytelen gondolatok kifejezésére szolgál (id. Frenkl, 1987).

A Világjátékban megjelenik egy pszichés tér, amely alatt olyan több síkon megnyilvánuló személyiségdinamikát értünk, melyben jelen van az átélt vagy fantáziált múlt, a jelen feszültségei és az a jövô, mely a vágyakból és anticipált félelembôl tevôdik össze. A világjátékban a pszichés teret három szinten ragadhatjuk meg: (1) a tárgyak szimbolikájában, (2) a térszimbolikában és (3) abban a pszichés mélységben, amivel a terapeuta közvetlen kapcsolatba tud lépni. Ezt a mélységet magával a történet explorálásával, illetve a felhívó kérdésekkel érhetjük el (Frenkl, 1987).

A tárgyak szimbolikáját, illetve az adott tárgyak jelentését nem pusztán a vizuális információ alapján értékeljük. A személyiség múködésének és dinamikájának megértéséhez a vizuális információn túl az építmény részletes explorációja is elengedhetetlen (Frenkl, 1987).

A téri szimbolika szerepét a világjátékban Roger Mucchielli dolgozta ki (forrásmegjelölés nélkül id. Frenkl, 1987; Polcz, 1999). A téri szimbolika alaptétele, hogy a befejezett struktúra kifejezi az épító saját történetét. A világ építése a cselekvésen keresztül valósul meg. Maga a beépítendô tér kifejezô mozgások hordozója, maga az építmény pedig annak manifesztációja, hogy milyen módon viszonyul az egyén a térhez és a külvilághoz. A térszimbolika alapja a saját testkép, amelyben a megélt tér belsôvé válik, így az egyén saját struktúrája alapján tájékozódik a megélt térben. A térszimbolika felhasználásával megkísérelhetjük leolvasni az épító élettörténetének traumatikus múltbeli történéseit, azokat a vágyakat és félelmeket, törekvéseket, melyek a jelenben hatnak, valamint a jövôre irányuló vágyait, szükségleteit. Frenkl (1987) az eredeti 6-os felosztást 9-es felosztássá bóvítette, ezt a 9. táblázatban ismertetjük. A térszimbolikai értelmezéssel kapcsolatban fontos tényezô, hogy 7-8 éves kortól alkalmazható, továbbá hogy balkezes személy esetén a múlt és a jövố szférája megcserélődik (Frenkl 1987).

A felhívó kérdések és a Világjáték szimbolikus értelmezése további mélységet adott a teszt értelmezésének, és kutatási lehetôségeket rejt a teszt diagnosztikai felhasználásában. Sajnálatos módon ezek a lehetôségek kiaknázatlanok maradtak, mert az elmúlt évtizedekben elmaradtak a Világjátékkal kapcsolatos hazai kutatások. Csenki, K. Németh és Pászthy $(2007,2009)$ anorexia nervosás prepubertás és pubertás korú (8-17 éves) lányoknál használták a tesztet a kórkép jellegzetességeinek leírására. A kezdeti 20, majd 50 fôs mintán olyan érzelemszabályozási deficitek jelentek meg a Világjátékok elemzésekor, melyek a pszichopatológiai kórkép számos aspektusát megragadják: 
9. táblázat. A Világjáték-teszt térszimbolikai értelmezése (Frenkl, 1987)

\begin{tabular}{l|l|l}
\hline \multicolumn{3}{c}{ Frenkl Sylvia térszimbolikája (1987) } \\
\hline \multicolumn{1}{c}{ Múlt } & \multicolumn{1}{c}{ Jelen } & \multicolumn{1}{c}{ Jövố } \\
\hline $\begin{array}{l}\text { A vágyott, idóben távoli, de } \\
\text { ma is ható élmények }\end{array}$ & $\begin{array}{l}\text { Az aktuális vágyak és remé- } \\
\text { nyek }\end{array}$ & A vágyott messzi jövó \\
\hline Múltbeli félelmek & $\begin{array}{l}\text { Énközeli, a személy életterét } \\
\text { tudatosan alkotó vágyak képe }\end{array}$ & $\begin{array}{l}\text { A közeli jövốre irányuló vá- } \\
\text { gyak vagy félelmek }\end{array}$ \\
\hline $\begin{array}{l}\text { A múltban átélt tudattalan } \\
\text { félelmek helye }\end{array}$ & Az aktuális élettér & $\begin{array}{l}\text { A jövôre vonatkozó, de aktuá- } \\
\text { lis szükségletek szimbólumai } \\
\text { jelennek meg }\end{array}$ \\
\hline
\end{tabular}

kognitív torzítás és beszúkülés, perfekcionizmus, érzelmi elárasztottság, izoláció és hasítás, diszfunkcionális intrafamiliáris múködésmódok, orális kielégületlenség, agresszió, szexualitás és bûntudat, valamint az identitás kérdése. A Világjátékban talált szabályozási jellegzetességeket Csenki (2012) érzelemszabályozást vizsgáló operacionalizálható verbális és nem verbális mérôeszközökkel is alátámasztotta.

\section{ÖSSZEFOGLALÁS ÉS KITEKINTÉS}

A Világjáték-teszt a klinikai pszichológia történetében és jelenében fontos helyet tölt be. Míg a múltban kutatások és vizsgálatok alanya volt, a jelenben a gyakorlati klinikai munka része. Mint láttuk, a tudományos megközelítés egyre inkább háttérbe szorult, és az elmúlt közel 30 évben alig született a témában kutatásra épülô munka. A gyakorlati tapasztalatunkból kiindulva úgy éreztük, hogy ez a projektív technika sokkal több és mélyebb pszichodiagnosztikai lehetôséget rejt magában, mint amelyeket múltbeli vizsgálatok és módszertani elgondolások alapján feltérképeztek. Ezekre építve tervezzük a Világjáték-teszt széleskörú felmérését az egészséges és klinikai gyermekpopulációban, melynek során célunk, hogy a teszt felvételének és értékelésének dimenzióit is egységesíteni tudjuk. Ennek a munkának az elsô lépése volt a Világjáték-teszt teljes nemzetközi és hazai történetének áttekintése, melynek eredménye a jelen tanulmány.

\section{KÖSZÖNETNYILVÁNÍTÁS}

A szerzôk köszönetüket fejezik ki Dr. Frenkl Slyvia és K. Németh Margit szakmai támogatásáért, mely inspirálta és segítette a tanulmány megszületését.

Külön köszönjük Cseh Éva felbecsülhetetlen segítségét a szakirodalmak beszerzésében. 


\section{IRODALOM}

Bolgar, H., \& Fischer, K. L. (1947). Personality projection in the World Test. American Journal of Orthopsychiatry, 17, 117-128.

Bowyer, L. R. (1970). The Lowenfeld World Technique. Studies in Personality. Oxford: Pergamon Press

Buhler, C. (1951a). The World Test, a projective technique. In C. Buhler, G. K. Lumry, \& H. S. Carrol (Eds), World-test standardisation studies. The Journal of Child Psychiatry, 2, 4-24.

Buhler, C. (1951b). Summary. In C. Buhler, G. K. Lumry, \& H. S. Carrol (Eds), World-test standardisation studies. The Journal of Child Psychiatry, 2, 66-69.

Buhler, C. (1951c). The World Test: Manual of Directions. In C. Buhler, G. K. Lumry, \& H. S. Carrol (Eds), World-test standardisation studies. The Journal of Child Psychiatry, 2, 69-82.

Buhler, C., \& Carrol, S. H. (1951). A comparison of the result of the world test with the teacher's judgment concerning children's personality adjusment. In C. Buhler, G. K. Lumry, \& H. S. Carrol (Eds), World-test standardisation studies. The Journal of Child Psychiatry, 2, 36-68.

Csenki L. (2012). Érzelemszabályozás serdülôkori anorexia nervosában. Pécsi Tudományegyetem Pszichológia Doktori Iskola

Csenki L., K. Németh M., \& Pászthy B. (2007). A világjáték jellegzetességei a gyermek- és serdülôkori anorexia nervosában. Serdülō-és gyermekpszichoterápia, 5, 25-44.

Csenki L., K. Németh M., \& Pászthy B. (2009). Játékszabályok. A szabályozás jellegzetességeinek bemutatása serdülókori anorexia nervosában a világjátékon keresztül. Psychiatria Hungarica, 24(5), 328-337.

Fischer, K. L. (1950). A new psychological tool in junction clinical experience with the Bolgar Fischer World test. American Journal of Orthopsychiatry, 20, 281-292.

Frenkl S. (1987). A pszichés tér megjelenése a világtesztben. Elôadásjegyzet 1987. szeptember

Hutton D. (2004). Test of Time. Margaret Lowenfeld's World Technique. Clinical Child Psychology and Psychiatry, 9(4), 605-612.

Kamp, L. N. J., \& Kessler, E. S. (1970). The World Test: Developmental Aspects of a Play Technique. Journal of Child Psychology and Psychiatry, 11, 81-108.

Lowenfeld, M. (1939). The World Pictures of Children. British Journal of Medical Psychology, 18, 65-101.

Lowenfeld, M. (1950). The nature and use of the Lowenfeld World Technique in work with children and adults. The Journal of Psychology, 30, 325-331.

Lumry, K. G. (1951). Study of World Test characteristics as a basis for discrimination between various clinical categories. In C. Buhler, G. K. Lumry, \& H. S. Carrol (Eds), World-test standVardisation studies. The Journal of Child Psychiatry, 2, 24-36.

Mérei F. (1974). Dramatizálás és jelképezés a játékban. In Mérei F. Szakács F. (Eds), Klinikai pszichodiagnosztikai módszerek (pp. 138-148). Budapest: Medicina.

Polcz A. (1966). A világ-technika módszerének hazai diagnosztikai és terápiás alkalmazása. Magyar Pszichológiai Szemle, 23, 158-167.

Polcz A. (1999). Dinamikus játékdiagnosztika és játékterápia. Budapest: Pont Kiadó 


\section{THE HISTORY OF WORLD TEST}

\section{CSENKI, LAURA - JAMBRIK, MÁTÉ}

The aim of the study is to provide a comprehensive historical overview of the development of the World Test and present its relevance in research and diagnostics. The literature review goes all the way back to 1937, when the test was first published. It discusses the theoretical basis of the creation of the test, its critiques, and studies aimed at its standardization. The World Test is a psychodiagnostic tool, and the question of its applicability in clinical work has been crucial since its publication. Classical research has explained the specific symptomatic signs, and the resulting symptomatic patterns appearing in the test, differentiating between healthy and pathological functioning. It supposes that the characteristics of healthy children can be used to define developmental norms or configurations that can be observed in an adult sample as well. Hungarian research of the World Test has demonstrated deeper connections and dynamic content that can be explored with the aid of invoking questions and symbolic analysis, going beyond the descriptive characteristics already employed. Research of the World Test decreased by the 1970s and 1980s, and in the lack of modern research methodology and fresh results, the old ones - just like in the case of other projective tests - may seem more and more outdated. Still, the test is widely used in practice, so the development of uniform administration and assessment criteria is needed. The theoretical and methodological overview creates a foundation for that.

Keywords: World Test, projective test, clinical psychology, psychodiagnostics 